\title{
HEGELOVA METAFYZIKA BOŽÍHO VTĚLENÍ A JEJÍ KRITIKA
}

\author{
Ivan Landa
}

\section{Úvod}

Mezi ústřední christologické otázky patří otázka: Cur deus homo? Ve vyznáních staré církve na ni nalézáme soteriologickou odpověd’: Bůh se stal člověkem ,pro nás a pro naše spaseni' “. ${ }^{1}$ Podle této odpovědi je účelem božího vtělení spasení. - Hegel uvedenou soteriologickou odpověd' beze zbytku přijímá a současně ji radikalizuje, nebot' se domnívá, že bez božího vtělení není možné spasení. Ve své vlastní úvaze, v níž důkladněji promýšlí událost božího vtělení, vychází z faktu božího vtělení v dějinné osobě Ježíše Nazaretského a ze skutečnosti Kristova spásného působení, jímž se narovnává porušený vztah mezi člověkem a Bohem a jímž se překonává jejich vzájemné odloučení. V této souvislosti si klade otázku, jaké další metafyzicky nutné podmínky jsou ve hře. V Přednáškách o filosofii náboženství naznačuje směr, kterým se ubírá hledání odpovědi:

„Možnost smíření je dána jen potud, pokud se ví o jednotě božské a lidské přrirozenosti, která je o sobě: Člověk může vědět, že je zahrnut v Bohu, není-li pro něj Bůh ničím cizím a není-li on sám pouhým vnějškovým akcidentem na božské přirozenosti, nýbrž je-li zahrnut v Bohu v souladu se svou bytností, se svou svobodou.“2

1 Srv. Nicejsko-cařihradské, Athanasiovo a Chalkedonské vyznání in: Čtyři vyznání, vyd. R. Říčan a kol., Praha 1951, str. 29, 31, 33. Nejvlastnějším smyslem božího vtělení, jak v souvislosti s anselmovskou otázkou Cur deus homo? podotýká Brian Hebblethwaite, je právě ono „pro nás“, jehož teoretické uchopení má zásadní význam pro theologii i filosofickou antropologii. Srv. B. Hebblethwaite, Philosophical Theology and Christian Doctrine, Oxford 2005, str. 70.

2 G. W. F. Hegel, Vorlesungen über die Philosophie der Religion. Die vollendete Religion $(=V P R)$, Hamburg 1995. VPR III/1831, str. 236/pozn. (Cituji podle tohoto vydání ve formě: zkratka názvu, díl/ročník, stránka/řádek, příp. poznámka.) - V textové variantě $\mathrm{k}$ citovanému místu je to vyjádřeno přímočařeji: Bez vědění o jednotě božské a lidské přirozenosti není možné smírení. A současně je zde nejenom řeč o tom, že člověk je zahrnut v Bohu ,,v souladu se svojí svobodou 
Hegel, jak patrno, dává možnost spasení potažmo smíření do př́ímé souvislosti s věděním: bez vědění není možné spasení, přičemž toto vědění samo není možné bez božího vtělení. Jedná se přitom o vědění, jehož obsahem je skutečnost, že božská a lidská přirozenost tvoří jednotu, že božství a lidství nejsou vzájemně odloučené momenty, resp. že lidství je nutnou součástí božství. Jednota dvou přirozeností, pro kterou razí Hegel titul „idea“, je jím považována za substanci lidství. Je v člověku přítomna „o sobě“، což znamená, že pro člověka není čímsi epistemicky průzračným. Otázka podmínek, za nichž je možné spasení či smíření, tak těsně souvisí s otázkou, za jakých podmínek se idea neboli jednota božské a lidské přirozenosti může člověku stát epistemicky transparentní. Hegelovo stanovisko, jež tvoří jádro jeho metafyziky božího vtělení, lze proto shrnout $\mathrm{v}$ několika tvrzeních: Bůh se musel zjevit ve formě individuality, a to dokonce ve formě lidské individuality. Nestačí tedy, aby se Bůh stal kterýmkoli předmětem v prostoru a čase. Musí se stát individuální bytostí, resp. člověkem. Kromě toho se musí zjevit v jedné jediné konkrétní bytosti zde a nyní. Boží vtělení je přitom jedinečné. Bůh se musel vtělit jednou, na jednom místě a v jedné dějinné osobě. ${ }^{3}$ Otázkou zároveň je: Proč se Bůh musel zjevit ve formě individuality? A proč by se nemohl zjevit $\mathrm{v}$ jiné než lidské formě, např. ve formě neživého předmětu nebo živočicha, jak to líčí jiná světová náboženství? A nakonec: Proč by se nemohl zjevit vícekrát, na různých místech a v různých lidech?

a subjektivitou“, ale současně je řečeno, že „, Bohu samém“ se nachází „tato subjektivita lidské přirozenosti“. Varianta má toto znění: „Možnost smířní spočívá jenom ve vědění o jednotě božské a lidské přirozenosti, která je o sobě; to je nutný základ. $Z$ tohoto důvodu lidská bytost může o sobě samé vědět jako o bytosti, která je zahrnuta $v$ Bohu, pouze když pro ni Bůh není něčím cizím a když vůči němu není ve vztahu pouze vnějškového akcidentu..., nýbrž je v Bohu zahrnuta v souladu se svojí bytností, v souladu se svojí svobodou a subjektivitou...; to je však možné pouze tehdy, pokud je v Bohu samém tato subjektivita lidské prrirozenosti.“

3 Tato tvrzení shrnují Hegelovo stanovisko, jak je nastínil v přednáškovém rukopise z roku 1821, aniž by je v následujících letech výrazněji modifikoval. Hegel však měl roku 1821 původně v úmyslu rozlišit dva analytické kroky: V prvním kroku zamýšlel blíže objasnit, že božská idea je „o sobě“ bezprostředně přítomná ve všech lidech, přičemž ve druhém kroku se hodlal zaměřit na rozbor teze, podle které se božská idea realizuje pro lidi ve formě výlučného dějinného individua. Později však na okraji svého rukopisu mezi oba kroky včlenil ještě třetí, v němž se soustředil na moment lidské individuality. Tuto kompoziční změnu a strukturu Hegelovy argumentace detailněji probírá P. C. Hodgson, Hegel and Christian Theology: A Reading of the Lectures on the Philosophy of Religion, Oxford 2005, str. $160 \mathrm{n}$. 
Metafyzika božího vtělení se po Hegelově úmrtí stala předmětem sporů, protichůdných interpretací a kritiky. Asi nejzajímavější a svého času nejvlivnější byly výhrady z pera theologa Davida F. Strausse. V obsáhlém spise Život Ježišuo v vydaném v roce 1835 se Strauss mj. podrobněji zabýval Hegelovou tezí, podle které boží vtělení představuje jedinečnou událost. Strauss vưči ní namítal, že právě tato teze činí christologii nekonsistentní a vystavuje ji vážným námitkám. Je-li totiž nanejvýš jedna dějinná osoba božská i lidská, znamená to, že jí lze připisovat vlastnosti, které nejsou slučitelné. Aby ji uchránil před logickou inkonsistencí, opouští Strauss důraz na jedinečnost božího vtělení ve prospěch jeho naprosté obecnosti. Je přesvědčen, že tímto zůstává práv Hegelově původní intenci vyjádřené v tvrzení, že každý člověk je „o sobě“ instancí jednoty božské a lidské přirozenosti. Rozvinutím Hegelovy původní intence, kdy se z každého člověka dělá exemplář božské ideje, můžeme podle Strausse přeformulovat tradiční christologii z hlediska filosofie dějin. Nahlíženo z této perspektivy jsou dějiny lidstva či lidského rodu ustavičným zjevováním božské ideje v prostoru a čase. Straussův interpretační př́istup tak ústí ve zjištění, že subjektem christologických výpovědí není Ježíš Kristus, ani jakýkoli jiný jednotlivý člověk. Je jím obecnost lidského rodu, která se realizuje v dějinách a stává se člověku více a více epistemicky průzračnou.

V následujícím výkladu nejprve stručně představím Hegelovo pojetí ideje a pojmu, jež tvoří pozadí úvah o jednotě božské a lidské přirozenosti, zastavím se krátce u Hegelovy představy, podle které je každý člověk „o sobě“ jednotou božské a lidské přirozenosti, a objasním ji v kontextu pojetí ideje a pojmu. Poté přikročím k rekonstrukci Hegelových argumentů ve prospěch teze, že boží vtělení se váže na lidskou individualitu. Následně v dalším kroku se budu více věnovat otázce jedinečnosti božího vtělení. Vzápětí obrátím pozornost ke kritickému ohlasu na Hegelovu metafyziku božího vtělení, zejména na kritiku od Davida F. Strausse. V závěrečném kroku se zastavím u oprávněnosti Straussovy kritiky a možné repliky z pozic Hegelovy inkarnační a dějinné koncepce.

\section{Idea: jednota božské a lidské přirozenosti}

Jedním z klíčových bodů Hegelovy metafyziky božího vtělení je antropologická teze, že každý člověk je „o sobě“ instancí božské ideje, resp. že pojmem člověka je jednota božské a lidské přirozenosti. Je proto zapotřebí osvětlit, jak Hegel užívá výrazy „idea““a „pojem“. - Jak známo, 
Hegel rozvrhl svébytné pojetí ideje a pojmu, jímž se vědomě odlišil od předchozí filosofické tradice (i když na ni také navázal). Zjevně nechce pojímat ideu jako konkrétní představu znázorňující určitou kvalitu, např. červenou barvu, anebo nějaký objekt prostřednictvím jeho kvalit, např. tohoto člověka; a zavrhuje rovněž pojetí, v němž je pojem chápán jako obecná či abstraktní představa, napřr. člověka jako takového nebo červené vůbec, jež postihuje druh objektu či kvality pomocí určitých podstatných rysů, díky nimž objekty či kvality spadají pod prŕíslušné pojmové abstrakce. ${ }^{4}$

Hegel přichází s odlišnou koncepcí, podle níž je pojem něco konkrétního, co je „principem všeho života“. 5 Tato koncepce zčásti souzní, jak sám přiznává, s formalistním náhledem, jenž ztotožňuje pojem s myšlenkovými formami. Hegel však upozorňuje, že v př́ípadě pojmu máme co do činění s „nekonečnou“ a „tvořivou“ formou. Pojem je forma vytvářjící ze sebe svůj vlastní obsah; není tedy bezobsažnou a statickou formou, kterou by myšlení jednoduše používalo jako nástroje při poznávání konkrétního obsahu. ${ }^{6}$

Vyjděme z Hegelova tvrzení, že pojem je forma, jež je zdrojem pohybu a principem spontaneity. Můžeme je rozvést pomocí př́kladu organismů, jímž Hegel nezř́idka ilustruje své chápání pojmu. Pohlížíme-li na pojem jako na formu imanentní organismům, tj. jako na soubor dispozic či schopností usměrňujících a určujících vývoj rostliny nebo živočicha, lze říci, že skrze vývoj je těmto dispozicím a schopnostem propůjčována realita či objektivita, takže rostlina nebo živočich se stává ,,pro sebe“ tím, čím je již „o sobě“.7 To, co se během vývoje mění, je vnější

4 Hegel říká: „Ideu samu nelze chápat jako ideu něčeho, stejně jako nelze pojem chápat jen jako určitý pojem.“ G. W. F. Hegel, Malá logika, přel. J. Loužil, Praha 1992, § 213, pozn.

5 Tamt., $\S 160$, dodatek.

6 Tamt., § 42, 2. dodatek.

7 G. W. F. Hegel, Dějiny filosofie, I, přel. J. Cibulka - M. Sobotka, Praha 1961, str. $57 \mathrm{n}$. Hegel se často ohrazuje vůči tomu, aby jeho chápání vývoje nebylo zaměňováno s preformační hypotézou: „Tak např. rostlina se vyvíjí ze svého semene, jež v sobě už obsahuje celou rostlinu, ale jen ideálně, takže její vývoj nelze chápat tak, jako by různé části rostliny - kořeny, lodyha, listy atd. - byly v semeni už reálně, avšak jen zcela malé. To tvrdí takzvaná preformační hypotéza." V pojmu rostliny, jímž je semeno, je tedy ideálně a ne reálně obsaženo, čím se rostlina v organickém vývoji stane. G. W. F. Hegel, Malá logika, § 161, dodatek. U Hegela i tak přetrvává jistá ambivalentnost. Na jednu stranu připouští, že u pojmu prostoročasových objektů většinou usuzujeme z realizací na pojem, což znamená, že k pojmu té či oné rostliny nebo živočicha se dobíráme výlučně empiricky. Ale na druhé straně hájí 
forma, zatímco imanentní forma přetrvává (např. rostoucí jilm realizuje svůj pojem, který se nemění, takže jilm se ve vývoji nestává javorem nebo lípou). Analogicky můžeme prohlásit, že duchovní útvary, např̀. instituce nebo náboženské systémy, též procházejí vývojem, který lze popsat pomocí rozdílu mezi „bytím o sobě“ a „bytím pro sebe“, možností a skutečností, idealitou a realitou. Je však možné tak učinit s jednou výhradou. Duchovní fenomény oproti přírodním zahrnují jednak vědění, jednak vztah k sobě. Přestože se zdá, že i v přírodě narážíme na fenomény vyznačující se reflexivitou, ve skutečnosti je tento typ vztahu naší projekcí a součástí našeho popisu, nikoli fenoménů samých; nemluvě o tom, že př́rodní fenomény postrádají epistemický charakter.

Rozdíl týkající se realizace pojmu u přírodních a duchovních fenoménů Hegel konkretizuje následovně: $\mathrm{V}$ př́padě organismů je rozdíl či „zdvojení“ mezi „bytím o sobě“ a „bytím pro sebe“ organismům vnější. Jinak je tomu v př́padě ducha, kde terminus a quo a terminus ad quem vývoje tvoří vnitřní strukturu duchovních fenoménů samých:

„U přírodních předmětů dochází ovšem k tomu, že subjekt, jenž proces začal (např. semeno), a existující předmět, jenž proces ukončuje (např. plod), jsou dvě individua. Zdvojení zde má zdánlivý výsledek, že se rozpadlo ve dvě individua, jež jsou ale co do svého obsahu týmž. Právě tak v životě zviŕrat jsou rodiče a děti rozdílná individua, i když téže povahy. Avšak v oblasti ducha je tomu jinak. Jde tu o vědomí, jež je proto svobodné, že $\mathrm{v}$ něm začátek a konec spadají $\mathrm{v}$ jedno. Sice i duch se obdobně jako zárodek v přírodě vrací zpět v jednotu poté, co se učinil jiným. Ale co je o sobě, to v tomto př́ípadě nastane pro ducha, a tak se stane duchem pro sebe. Naproti tomu plod a v něm obsažené nové semeno nenastanou pro onen první zárodek, nýbrž pro nás. “68

U duchovních útvarů je tak pojem možností, idealitou či subjektivitou, jež si propůjčuje skutečnost, realitu či objektivitu. Vývoj pojmu se přitom završuje tehdy, dosáhne-li duch vědění o sobě samém a stane-li se mu transparentní jeho vlastní pojem: duch je pak pro ducha, takže duch

názor, že z pojmu lze usuzovat na možné realizace, jako např. z pojmu Boha nebo z pojmu člověka. Z toho důvodu mu někdy bývá vyčítáno, že a priori konstruuje podobu sociální reality a průběhu dějin z pohodlí své lenošky, když analyzuje a rozvíjí jejich pojem (at' už je jím pojem svobodné vůle či pojem svobody).

8 G. W. F. Hegel, Dějiny filosofie, I, str. 58 n. 
ví o sobě samém jen skrze ducha. Pojem jako činná forma je tak zárodečné vědění o sobě, která se postupně uskutečňuje.

Ve spekulativní logice, zejména v pasážích pojednávajících výslovně o pojmu, Hegel sleduje toto uskutečňování pojmu v elementu myšlení, vycházeje z již připomínané skutečnosti, že pojem není bezobsažnou a statickou formou, nýbrž je principem spontaneity. Na jednom místě přitom Hegel přímo ztotožňuje pojem s Já neboli s čistým sebevědomím, když poznamenává, že Já je původním věděním o sobě samém vyznačujícím se jednak obecností, jednak jednotlivostí. ${ }^{9}$ Já je totiž podle něj něčím, co je pro sebe. A nakolik je Já pro sebe, odhlíží od něčeho jiného, tj. od veškerého určitého obsahu, jemuž by náležela samostatná existence nezávisle na Já: potud je Já absolutní obecností. Ale jelikož Já „se staví proti jinému a vylučuje je“, je ve hře také ohled, třebaže negativní, vůči něčemu jinému: potud je Já ,absolutní určeností“, tj. jednotlivostí či „,individuální osobností (Persönlichkeit)“. Hegel tedy postihuje povahu pojmu takto: „Povahu Já jako pojmu“ utváríi „,absolutní obecnost, která je právě tak bezprostředně absolutní partikularizacíi. ${ }^{10}$

Odtud lze učinit krok k Hegelovu pojetí ideje. Nebot' pojem - Já, čisté sebevědomí - je spontaneitou, jež nachází své uplatnění, vytváří-li

9 G. W. F. Hegel, Wissenschaft der Logik. Die Lehre vom Begriff (1816), Hamburg 1994, str. 12.

10 Tamt., str. 12 n. Srv. také pasáže o myšlenkovém určení „,bytí pro sebe“. G. W. F. Hegel, Wissenschaft der Logik. Die Lehre vom Sein (1832), Hamburg 1990, str. 159-162. Stojí za zmínku, že tuto povahu Já později postihl stejným zpo̊sobem Gottlob Frege, přestože úvahy o čistém sebevědomí u něj hrají okrajovou roli. Frege si totiž primárně klade otázku smyslu věty a přitom naráží na zvláštní druh vět, které obsahují index ,já“. V souvislosti se smyslem tohoto indexického výrazu uvádí následující: „Každý je dán sám sobě zvláštním a původním způsobem, kterým není dán nikomu jinému. Jestliže si nyní dr. Lauben myslí, že byl zraněn, pak jde přitom pravděpodobně o tento původní způsob, jak je dán sobě samému. A takto určitou myšlenku může uchopit jen dr. Lauben sám.“ Srv. G. Frege, Myšlenka. Logické zkoumání, přel. J. Fiala, in: Scientia \& Philosophia, 6, 1994, str. 60. Zvláštní druh vět, obsahujících index ,já“, vyjadřuje myšlenku, kterou může uchopit jen mluvčí či ten, kdo ji právě myslí, takže jen stěží může tuto myšlenku sdělit někomu jinému. To, že každý je dán sobě samému zcela původním způsobem, vyjadřuje obecný způsob danosti. Ale současně se jedná o zvláštní způsob danosti, resp. o jedinečnou epistemickou perspektivu, nebot' jsem takto dán jen sobě samému a nikomu jinému. Ostatním jsem dán jako někdo, kdo splňuje ten či onen popis, resp. jako nositel toho či onoho jména, tj. zprostředkovaně, zatímco sobě samému právě nejsem dán prostřednictvím určitého popisu či vlastního jména, ale bezprostředně. Srv. detailnější diskusi Fregovy teorie indexických výrazů v souvislosti s otázkou apriorní sebeidentifikace v knize A. F. Koch, Subjektivität in Raum und Zeit, Frankfurt a. M. 1990, str. 216 n. 
ze sebe svůj obsah. A tímto obsahem je systém myšlenkových určení a forem, v nichž a skrze něž pojem získává objektivitu. $\mathrm{Z}$ tohoto úhlu pohledu viděno je idea „absolutní jednota pojmu a objektivity“, resp. absolutní jednota subjektivity a objektivity, přičemž Hegel se domnívá, že jedinými instancemi ideje jsou bytosti, které disponují sebevědomím, tj. lidské bytosti. ${ }^{11}$

Po této oklice se dostáváme $\mathrm{k}$ jádru antropologické teze, podle níž každý člověk je „o sobě“ instancí božské ideje. Je výslovně vyjádřena v přednáškovém rukopise z roku 1821, kde Hegel rríká: „Idea je přítomna... o SOBĚ, boží objektivita je realizována - a to bezprostředně ve všech lidech."12 Na jiném místě rukopisu dále poznamenává, že každá lidská bytost si „O sOBĚ v sobě samé nese božskou ideu“, resp. že každý člověk si „,v sobě nese [ideu] jako svou substanciální povahu, jako své vlastní určení či jako jedinečnou možnost takového určení - a tato nekonečná možnost je jeho subjektivitou““. ${ }^{13}$ - Hegel je zjevně přesvědčen o tom, že božská idea tvoří pojem, tj. podstatu či přirozenost, každého člověka a dále že má objektivitu „ve všech lidech“. Nebot' každý člověk ztělesňuje jedinečnou epistemickou perspektivu, z níž je dán sobě samému. Božskou ideu tudíž nelze smysluplně považovat za transcendentní vůči člověku a tomuto světu, jak to zpravidla činí teistická náboženství: „Mluvíme-li o ideji, nepředstavujeme si ji jako něco vzdáleného a z onoho světa. Idea je něco naprosto přítomného, a lze ji proto nalézt v každém vědomí, i když zkalenou a zakrnělou. “"14

Tuto imanenci ideje, její „zde“ a „nyní, upřesňuje Hegel pomocí tvrzení, že božská idea je přítomná „,v každém vědomi“, přestože, jak neopomine $\mathrm{v}$ uvedeném úryvku zdůraznit, pouze ,zkaleně“ či „,zakrněle“. To znamená, že pro bytosti disponující sebevědomím není idea transparentní skutečností, ačkoli netematicky je přítomná v každém z jejich mentálních stavů a i když se manifestuje na úrovni jazyka v užívání indexu ,jáa“. Idea je totiž podmínkou, za níž si mohu být vědom určitých mentálních stavů jako svých vlastních. Když např. pocit’uji bolest, jsem si bezprostředně vědom určitého mentálního stavu jako svého, takže rovněž bez dalšího zprostředkování vím, že jsem to já, kdo bolest pocit'uje.

11 G. W. F. Hegel, Malá logika, § 213.

12 G. W. F. Hegel, VPR III/1821, str. 47/342-48/343. Textová varianta má toto znění: „Tato idea a objektivita Boha je o sobě též reálná v procesu, ve kterém jinakost překonává sebe samu..."

13 Tamt., str. 45/284-288.

14 G. W. F. Hegel, Malá logika, § 213, poznámka. 
Hegel tím chce pouze ozřejmit, že vědomí a naše běžné vědomí o sobě samých zahrnuje ještě původnější, čisté sebevědomí. Když si uvědomuji nějaký předmět, anebo sebe sama, je v těchto aktech zahrnut původnější způsob, jímž jsem dán sobě samému, tj. jedinečná, byt' současně universální epistemická perspektiva. Tato epistemická perspektiva se na rovině jazyka manifestuje v užívání indexického výrazu ,jáa“, v němž vystupují zřetelněji do popředí základní charakteristiky pojmu, totiž obecnost a jednotlivost. ${ }^{15}$ Hegel ovšem stejnou měrou akcentuje, že idea je v našem vědomí př́tomna netematicky: je pouhou možností, nikoli transparentní skutečností, jíž se může stát, dosáhne-li člověk vědění o ideji.

\section{Individuálnost božího vtělení}

Ústřední otázkou nyní je, zdali je možné, aby člověk nabyl vědění o božské ideji ${ }^{16}$ Hegel se domnívá, že nabytí vědění o ideji je možné pouze tehdy, když se idea člověku zjeví v podobě individua v prostoru a čase, resp. v lidské podobě. ${ }^{17}$ Bez vtělení, jak zní Hegelovo diktum, není možné vědění - a to ani o Bohu, ani o člověku samém. V posledních letech, kdy Hegel přednášel o filosofii náboženství na berlínské universitě, rozpracoval dva vzájemně provázané argumenty ve prospěch teze, podle

15 Hegel uvádí: „Když říkám: „Já, míním sebe jako tuto jednotlivou, zcela určitou osobu. Ve skutečnosti však o sobě nevypovídám nic zvláštního. I každý jiný je Já, a označím-li sebe jako ,Já‘, pak sice míním sebe, tuto jednotlivinu, vypovídám však zároveň něco naprosto obecného.“ G. W. F. Hegel, Malá logika, § 24, 1. dodatek. Když užiji index ,,já“, aniž připojím predikát, nevypovídám o sobě ještě nic zvláštního, nebot' odhlížím od jakéhokoli určitého obsahu, resp. od vlastností, které mne individualizují jako tuto konkrétní osobu, čímž jsem ,povznesen nad každé místo, národnost, stav, životní situaci atd.“ VPR III/1821, str. 45/290.

16 Hodgson rekonstruuje Hegelovu metafyziku božího vtělení na základě tří modalit: možnosti, nutnosti a skutečnosti. Možnost smíření souvisí s tím, že člověk je v možnosti či implicite jednotou božské a lidské přirozenosti. Nutnost spočívá v tom, že tato jednota se musí jevit. Skutečnost je dána spolu s podobou člověka, v níž se Bůh zjevuje. P. C. Hodgson, Hegel and Christian Theology, str. 155-163. S načrtnutou rekonstrukcí souhlasím, i když se domnívám, že Hegel buduje svoji úvahu v obráceném sledu na způsob transcendentálního argumentu: vychází ze skutečnosti a ptá se po nutných podmínkách, za nichž je tato skutečnost možná. Jádro argumentace však není strukturováno podle modálních určení, nýbrž na základě určení, jež jsou příznačná pro pojem, a sice podle určení obecnosti, zvláštnosti a jednotlivosti.

17 „Idea se realizuje... pro lidi; její jev a jsoucno je jen v tomto jednotlivci.“ $V P R$ III/1821, str. 48/358. 
které se Bůh musel stát člověkem. Oba argumenty ovšem mají odlišná východiska. Zatímco v prvním se zohledňuje omezená kognitivní výbava člověka, druhý naopak objasňuje událost božího vtělení ve světle svébytného pojetí (božské) ideje, podle něhož se idea může plně uskutečnit za předpokladu, že získá objektivitu, a to v podobě jednotlivého člověka.

První argument beroucí v potaz nedostatečnou poznávací vybavenost člověka lze rozčlenit do dvou kroků, z nichž jeden zdůrazňuje individuálnost, zatímco ten druhý lidskou podobu. Začněme argumentem ve prospěch individuálnosti božího vtělení, který je přehledně představen $\mathrm{v}$ Hegelových přednáškách z roku 1827. Ústředním předpokladem je zde tvrzení, že boží zjevení musí být principiálně př́stupné každému člověku. Pokud by zjevení bylo epistemicky př́stupné jen někomu a nepřístupné někomu jinému, bylo by restriktivní. Z restriktivní povahy zjevení by plynul nepřijatelný soteriologický důsledek: Jen někteří by mohli být spaseni. Ono „,pro nás“, tolik zdůrazňované ve vyznáních staré církve a vyjadřující nejvlastnější účel božího vtělení, by pak mělo význam ,jen pro některé“. Událost božího zjevování však zahrnuje, že Bůh se v principu stává epistemicky přístupným pro každého člověka. V tom je zapotřebí spatřovat universalistický nárok boží manifestace. Je tudíž vyloučeno, aby recepce manifestujícího se obsahu byla podmíněna zvláštnostmi na straně jeho př́ijemců, napřr. sociálním statusem, pohlavím, vzděláním nebo intelektuálními schopnostmi. ${ }^{18}$ „Pro nás“ znamená tedy „pro každého“.

$\mathrm{Z}$ toho můžeme usoudit, že forma, v níž je manifestující se obsah člověku dán, musí odpovídat nejelementárnější epistemické formě konečného lidského poznání. $V$ úvahu připadají dvě formy: názor a pojem, resp. nediskursivní a diskursivní poznání. Zatímco obsahem diskursivního poznání jsou obecné pojmy a propozice, obsahem smyslového nazírání je prostoročasová rozmanitost. ${ }^{19}$ Má-li forma zjevení odpovídat té nejelementárnější epistemické formě, musí být bezprostředně dána ve smyslovém nazírání. ${ }^{20}$ Božská idea tedy musí být pro člověka přístupná prvotně

18 Tamt., str. 46/314.

19 Dodejme, že Hegel rozlišuje dvě podoby nediskursivního poznání: smyslové a intelektuální nazírání. Intelektuální nazírání má za svůj obsah izolované pojmy, nikoli propozice. Srv. G. W. F. Hegel, Wissenschaft der Logik. Die Lehre vom Begriff (1816), str. 288.

20 Jak poznamenává Hegel, důležitá je zde „tato jistota a nazírání“, „,bezprostřednost jistoty a přítomnost božského“, nikoli zprostředkování skrze představy, pojmy, přesvědčení nebo důvody. VPR III/1821, str. 47/329. James Yerkes shrnuje jádro Hegelova argumentu slovy, že „zjevování musí vyhovovat metodě poznání, 
v nediskursivní formě smyslového nazírání či jistoty. ${ }^{21} \mathrm{~A}$ jelikož ve smyslovém názoru jsou nám dány prostoročasové jednotliviny, musel se Bůh zjevit v podobě prostoročasové jednotliviny. ${ }^{22}$

Universalistickému nároku zjevení tak může idea dostát jen tehdy, když se Bůh vtělí a stane se jednotlivinou v prostoru a čase, nebot' jen tímto způsobem je pro člověka epistemicky př́istupná, a to ve smyslovém názoru. - Hegel však činí ještě druhý krok. Zdůvodňuje v něm, že Bůh se nemohl zjevit $\mathrm{v}$ podobě ledajaké jednotliviny, např. kamene nebo zviŕrete, nýbrž že na sebe musel vzít podobu lidského individua. Tento krok vystupuje do popředí v přednáškách z roku 1824, kde se říká: „Bůh se... jeví ve smyslové přítomnosti; nemá žádnou jinou podobu nežli podobu smyslového modu ducha, který je o sobě; to je podoba jednotlivého člověka. Toto je jediná, smyslová podoba ducha. Bůh se jeví v těle.“23 Zčásti tento úryvek rekapituluje závěr předchozí úvahy. Ríká se v něm totiž, že jevení božské ideje se odehrává v těle, tj. ve formě prostoročasové jednotliviny. Ale kromě toho se v něm také tvrdí, že idea získává podobu jednotlivého člověka, protože lidské individuum je „smyslovým modem ducha“. Hegel přitom popírá, že by existovalo vícero smyslových modů ducha. Za předpokladu, že by jich existovalo vícero, by jistě bylo myslitelné, aby se božská idea zjevila i v jiných modech. ${ }^{24}$ Avšak

kterou člověk jako konečná bytost nakonec dospívá k pravdivému poznání čehokoli“. Poznání božské ideje tak „musí začít smyslovým vnímáním a musí mít svůj původ v konkrétním lidském životě“. J. Yerkes, The Christology of Hegel, Albany 1983, str. 134.

21 G. W. F. Hegel, VPR III/1827, str. 236/pozn.

22 Peter F. Strawson ve své interpretaci Kanta upozornil na to, že dualita názoru a pojmu, př́iznačná pro naše poznání, je systematicky provázána s dualitami, týkajícími se jak reality, tak způsobu, jakým o realitě mluvíme. P. F. Strawson, The Bounds of Sense, London 1966, str. 47. Epistemologické dualitě názor/pojem podle něj odpovídá jednak ontologická dualita mezi jednotlivinou a obecným druhem či vlastností, jednak jazyková dualita mezi singulárními a obecnými termíny. Jednotliviny, které jsou nám dány v názoru a k nimž se vztahujeme pomocí singulárních termínů: jmen, určitých popisů či indexických výrazů a demonstrativ, jsou instancemi druhů, myšlených - tj. klasifikovaných a popisovaných - pomocí pojmů a vyjadřovaných pomocí obecných termínů. Jednotliviny jsou nazírány nediskursivně a myšleny diskursivně v soudech. Domnívám se, že podobné stanovisko, které Strawson připisuje Kantovi, lze připsat i Hegelovi (svědčí o tom mj. pasáže z Fenomenologie ducha pojednávající o smyslové jistotě).

23 G. W. F. Hegel, VPR III/1824, str. 146/513-516.

24 Tvrzení, že duch má pouze jedinou smyslovou modifikaci, nesmí být vykládáno tak, jako by Hegel upíral mentální život vyšším živočichům. Hegel v rámci své teorie subjektivního ducha dokládá, že vyšší živočichové sice mají mentální život, 
jelikož neexistují alternativní smyslové mody ducha, zjevuje se božská idea právě v lidské podobě. ${ }^{25}$

Druhý argument, který Hegel rozvinul v pozdějších přednáškách, směruje ke shodnému závěru, byt' jinou cestou. Východiskem je myšlenka Boha, resp. jeho základní určení, podle něhož Bůh je bytostně idea neboli duch. Hegel v jedné z ústředních pasáží předkládá toto znění argumentu: „Jelikož duch ve svém nekonečném vztahu k sobě obsahuje určení bezprostřednosti, musí být rovněž v Bohu samém přítomen tento moment bezprostřednosti, má-li se člověku zjevit jako duch. Ale již se nejeví v př́rodní bezprostřednosti, které konec konců ani nebyl opravdu imanentní, jak tomu bylo u hořícího keře, nýbrž se jeví v duchovní bezprostřednosti, v lidské podobě. “26 - I v tomto príípadě se Hegelova úvaha odvíjí ve dvou krocích, zdůrazňujících jednou individuálnost, podruhé lidskou podobu.

O ideji, resp. o duchu se řeklo, že je původním věděním, pro něž je příznačný vztah k sobě samému. Je to epistemická struktura absorbující do sebe veškerou jinakost, jelikož toto vědění se realizuje prostřednictvím jiného, které je však součástí epistemické struktury a nemá existenci nezávislou na vědění. To znamená, že Bůh, pokud jej ztotožníme s ideou, je věděním, které ví o sobě samém prostřednictvím něčeho jiného: člověka, jenž se k Bohu vztahuje. Určení bezprostřednosti, jež je mu (vedle zprostředkovanosti) vlastní, je dáno právě tím, že objekt vědění je zahrnut v subjektu vědění. Má-li se nyní pro člověka stát zjevnou takto chápaná božská idea, musí se mu stát průzračnou tato struktura původního vědění, zahrnujícího jak bezprostřednost (vztah k sobě), tak zprostředkování (vztah k sobě prostřednictvím něčeho jiného). Ostatně to je důvodem, proč se božská idea musí zjevit jako něco empiric$k y$ bezprostředního, co se nalézá „zde“ a „nyni“. A jelikož empiricky

nicméně ten není životem ducha. Živočichové totiž nejsou sebevědomými, a proto ani svobodnými bytostmi. Hegel tedy spatřuje rozdíl mezi člověkem a ostatními Živočichy právě $\mathrm{v}$ př́itomnosti, resp. $\mathrm{v}$ absenci ducha.

25 Lze uvést ještě dodatečný důvod ve prospěch lidské individuality božího vtělení. Smyslem božího vtělení není jen poznání jednoty božské a lidské přirozenosti, ale také poznání, že tato jednota je substancí člověka jako takového. Hegel v přednáškách z r. 1827 poznamenává: „lidé si uvědomují substancialitu jednoty božské a lidské přirozenosti tím zpo̊sobem, že lidská bytost (nikoli však každá lidská bytost) se pro vědomí jeví jako Bůh a Bůh se mu jeví jako lidská bytost.“ (VPR III/1827, str. 236/707-237/710.) To, že idea je bytností každého lidského individua, si tedy mohou lidé exemplárně uvědomit na prrípadu lidského individua, které je explicitní jednotou božské a lidské přirozenosti.

26 G. W. F. Hegel, VPR III/1831, str. 283/162-169. 
bezprostřední jsou prostoročasové jednotliviny (např. tento člověk, tento keř, toto zvíře atd.), musí se zjevit jako jednotlivina $\mathrm{v}$ prostoru a čase. Ale musí jít o takovou jednotlivinu, jíž je idea vskutku imanentní, a to není ani případ keře, ani zvířete. $V$ potaz přichází výlučně jednotlivý člověk, nebot' božská idea se může stát imanentní jen té jednotlivině, která je sama bytostně instancí ideje. Tudíž Bůh se musel stát lidskou bytostí. ${ }^{27}$

Cílem předestřených argumentů je zdůvodnit individuálnost, a potažmo lidskou podobu božího vtělení. Stýkají se v přesvědčení, že receptivní poznání božské ideje ze strany konečného vědomí není možné bez spontánní aktivity ze strany božské ideje. A to má jeden závažný důsledek: Člověk se může stát pro sebe tím, čím je o sobě, pouze tehdy, když se božská idea sama stane pro sebe tím, čím je o sobě. Jestliže se božská idea plně uskuteční a realizuje svůj pojem, znamená to současně, že se plně uskutečnil také člověk jako takový, že realizoval svůj pojem.

\section{Jedinečnost božího vtělení}

Dosud nabídnuté argumenty nevylučují možnost vícečetných inkarnací a vlastně ji nechávají otevřenou. Je-li totiž smyslové nazírání epistemickou formou, jejímž obsahem je prostoročasová rozmanitost, a může-li být idea bezprostředně dána člověku pouze v příslušné formě, je také možné, aby se zjevila bud' souběžně, anebo následně v mnoha jednotlivých lidech. I když připustíme, že neexistují alternativní smyslové mody ducha a že člověk je jeho výlučným smyslovým modem, neznamená to ještě, že by fakticky nebo logicky musel existovat pouze jeden jediný člověk, který ztělesňuje a zjevuje božskou ideu. A právě tak lze tvrdit, že empirickou bezprostřednost může idea získat v mnoha lidských bytostech, nikoli jen $\mathrm{v}$ jednom jediném člověku.

Hegel však rozhodně odmítá možnost vícečetných, at' už simultánních či sukcesivních inkarnací. V přednáškovém rukopise z roku 1821 např. píše, že božská idea se pro lidi realizuje ,pouze v tomto jednotlivém individuu a POUZE JEDNO takové individuum - toto individuum - je nekonečná jednota (v této subjektivitě, $\mathrm{v}$,tomto')““ ${ }^{28}$ Je tedy zjevně přesvědčen

27 Např. ve Starém zákoně ovšem není řečeno, že Bůh je keř. Je zde spíše vykreslen jako ten, kdo skrze keř promlouvá $\mathrm{k}$ Mojžíšovi. V hořícím keři se ukazuje Hospodinův posel, nikoli Hospodin sám (Ex 3,2-4). Uvidíme, že téměř shodný argument užívá Hegel při vyvracení možnosti vícečetných inkarnací.

28 G. W. F. Hegel, VPR III/1821, str. 49/385-386. Tento bod Hegel akcentuje i na jiném místě: „Pro bezprostřední vědomí k tomu nemůže dojít žádným jiným 
o tom, že boží vtělení představuje jedinečnou a neopakovatelnou událost v dějinách: Bůh se může stát člověkem jedinkrát, a to v jedné konkrétní lidské bytosti. Jen tak totiž může mít vpravdě universální význam, který přichází ke slovu ve vyznáních staré církve. Nebot’ „pro nás“a a,pro naše spasení“ znamená, jak jsme výše řekli: „pro každého člověka“. Hegel je tedy toho názoru, že universálnost je podmíněna jedinečností: boží vtělení musí být jedinečnou událostí v dějinách. ${ }^{29}$ Jaké pádné důvody existují ve prospěch tohoto názoru?

V jedné hutné pasáži v Hegelově rukopisu z roku 1821 lze narazit na toto zdůvodnění: „V jednom jsou všechna; v několika se božství stává abstrakcí. Jedno je výlučné oproti všem, aby se tato všechna mohla obnovit [rekonstruieren]. “30 Vůdčí myšlenka, jež má opět zjevný soteriologický nádech, zní tedy tak, že pouze jedno lidské individuum může být pro člověka paradigmatickým exemplářem božské ideje. Pouze v něm totiž může být zahrnut každý jednotlivý člověk. Kdyby exemplářů ideje bylo vícero, jak tvrdí stěžejní výpověd', proměnilo by se božství v abstrakci. Vznikla by pak překážka bránící tomu, aby se lidské bytosti skrze paradigmatické individuum „obnovily“, tj. uskutečnily svůj pojem, a došly tak spasení. Je zde hned několik nejasností. Proto se zastavím u klíčových míst Hegelova argumentu, přičemž rozeberu jádro jeho výhrad vůči vícečetným inkarnacím.

způsobem, než že pro člověka se tato jednota ukáže $v$ naprosto časovém, ve zcela běžném, světském jevu, v tomto jediném člověku - v tomto člověku, o němž se zároveň ví, že je božskou ideou, nikoli učitelem, nikoli vyšší bytostí vůbec, nýbrž nejvyšší ideou, božim Synem.“ Tamt., str. 46/318-47/324.

29 Je třeba zmínit, že otázka jedinečnosti božího vtělení a problematika vícečetných inkarnací byla v theologických diskusích s novou intenzitou nastolena ve druhé polovině 20. století, kdy se stala předmětem rozepře mezi theology Brianem Hebblethwaitem a Johnem Hickem. Hebblethwaite uvažující v intencích křest’anské ortodoxní doktríny vyslovil domněnku, podle které je myšlenka vícečetných inkarnací v rozporu s křest’anskou doktrínou, v níž je výslovně zdůrazněno, že ,pouze jeden člověk pro nás může být skutečně Bohem, je-li Bůh jen jeden“. Lapidárně řečeno: Je-li Bůh jeden, pak se také může vtělit pouze jednou, na určitém místě a v jednom konkrétním člověku. Srv. B. Hebblethwaite, The Incarnation, Cambridge 1987, str. 189. Naproti tomu Hick uvažující v mnohem širším kontextu světových náboženství hájí logickou možnost vícečetných inkarnací. I když uznáme, že Bůh je pouze jeden, je podle něj myslitelné, aby se vtělil vícekrát. J. Hick, The Metaphor of God Incarnate, London 1993, str. 89-98. Domnívám se, že Hebblethwaitův postoj, že jen jedno individuum může být prostředníkem smíření, je bližší Hegelovu stanovisku.

30 G. W. F. Hegel, VPR III/1821, str. 49/381-384. 
Myšlenka mnohačetného vtělení má podle něj nejméně dva nepřijatelné důsledky (zohledníme-li předchozí argumentaci o individuálnosti a lidské podobě). Za prvé, uvedená myšlenka je v rozporu s požadavkem, aby božská idea byla dána $v$ nejelementárnější epistemické formě smyslového názoru, což nakonec maří její poznání. Za druhé, zmíněná myšlenka operuje s deficitním pojetím božství jako abstraktní obecnosti; božská idea tedy není chápána jako něco konkrétně obecného.

Podívejme se blíže na první bod. Pokud by se božská idea člověku manifestovala $\mathrm{v}$ mnoha exemplárích, mohl by o ní vědět pouze za předpokladu, že by si o ní vytvořil obecnou představu pomocí abstrakce z mnoha konkrétních př́padů. Mohl by ji poznat jen pomocí abstraktní představy vytvořené induktivně. Hegel se však domnívá, že by tak ve skutečnosti bylo znemožněno poznání božské ideje, nebot' existuje nebezpečí, že indukce zůstane neúplná. Během svého života se člověk bezprostředně konfrontuje jen s omezeným počtem existujících individuí; a právě tak zprostředkovaně, na základě popisu, ví jen o omezeném počtu již neexistujících individuí, nemluvě o tom, že nemá žádné povědomí o ještě neexistujících individuích. Připadá tudíž v úvahu možnost, že si vytvoří představu o božské ideji na základě nedostatečného počtu jejích instancí, a v důsledku toho nebude schopen spolehlivě udat, v čem spočívá božská povaha. Problém neúplné indukce, jak se zdá, nicméně odpadá, pokud se Bůh vtělil jednou a v jediném individuu.

Je zde ale jiná obtíž, která souvisí s neřešitelností problému kritéria. Kdyby se božská idea člověku zjevila v několika exemplárích, vyvstala by otázka, jak by člověk mohl rozpoznat, že právě toto a ne jiné individuum manifestuje božskou ideu. Člověk by musel mít k ruce pojmová určení, jež by mu dovolila udat, že exempláře, s nimiž se bezprostředně či zprostředkovaně konfrontoval, jsou instancemi božské ideje. To by ale znamenalo, že již fakticky má nějaké vědění o božské ideji. - Jak problém neúplné indukce, tak chybějícího kritéria hovoří podle Hegela v neprospěch myšlenky vícečetných inkarnací, resp. ve prospěch jedinečnosti božího vtělení: „Subjekt se musí obracet k subjektu, aniž by měl na vÝBĚr. Aby bylo toto jedno učiněno Svatým, k tomu je zapotřebí určité místo a výjimečná př́ležitost." ${ }^{\text {"31 }}$

Nyní se zaměřme na druhý sporný bod, podle kterého myšlenka vícečetných inkarnací operuje s deficitním pojetím božství jako abstraktní obecnosti. Toto pojetí prrímo souvisí s problémem neúplné indukce,

31 Tamt., str. 49/392-394. Pro Hegela tedy problém chybějícího kritéria výběru nevyvstává $\mathrm{v}$ případě jedinečnosti vtělení. 
o němž byla právě řeč. Utváŕí-li si totiž člověk představu o božské ideji induktivně, na základě konfrontace s různými individui, jež jsou jejími instancemi, zaměřuje se na to, co je jim všem společné, a odhlíží naopak od toho, v čem se liší, nemůže se tímto postupem dobrat $\mathrm{k}$ vědění o Bohu jako o něčem konkrétním, tj. jako o živém duchu, domnívá se Hegel. Bude mít totiž napořád co do činění pouze s myšlenkovým konstruktem Boha, nikoli s Bohem samým. Konkrétní obecnost je tak zaměněna za obecnost abstraktní. ${ }^{32}$

V pozdních přednáškách, které Hegel pronesl v roce 1831, je tento argument rozveden obšírněji:

„Na to, že Bůh se stal člověkem, jsme narazili v prŕípadě hinduistických inkarnací, dalajlámy, také u zbožštění řeckých hrdinů a římských císařů: ve všech těchto případech nacházíme snahu o určení o sobě jsoucí jednoty božské a lidské přirozenosti. Ovšem v těchto orientálních formách je lidství pouhou maskou, nikoli něčím skutečným. Zakládají se na představě, že duch se snížil na úroveň cizorodé ử $\eta$ a že se svým vtělením uvrhl do šatlavy. Na tom je kus pravdy, přestože $\mathrm{z}$ druhé strany můžeme určení ducha $\mathrm{v}$ takovéto subjektivitě považovat za jeho nejzazší vyhrocení, kterýžto moment nemůže v božském životě chybět.“33

32 G. W. F. Hegel, Malá logika, § 163, 1. dodatek. Hlavní pointu nastíněného Hegelova argumentu stručně shrnuje Walter Jaeschke: „Předpoklad plurality boholidských individuí protiřečí pojmu jednoty božské a lidské přirozenosti. Na vícero individuích by se božství stalo abstrahovatelnou kvalitou."W. Jaeschke, Die Religionsphilosophie Hegels, Darmstadt 1983, str. 98 n. Detailní rozbor Hegelova chápání inkarnační doktríny lze nalézt v knihách: J. Yerkes, The Christology of Hegel, Albany 1983, str. 111-170. S. Crites, Dialectic and Gospel in the Development of Hegel's Thinking, Pennsylvania 1998, str. 504-506. C. O'Reagan, The Heterodox Hegel, Albany 1994, str. 189-234. P. M. Merklinger, Philosophy, Theology, and Hegel's Berlin Philosophy of Religion 1821-1827, Albany 1993, str. 169-174. M. J. De Nys, Hegel and Theology, New York 2009, str. 123-136. Je třeba dodat, že Hegel chápe konkrétní obecnost jako „to, co se samo ozvláštňuje (specifikuje) a co zůstává v nezkalené zřetelnosti u sebe a ve svém jiném“. Jako příklad konkrétní obecnosti zmiňuje obecnou vůli, která ještě nemusí být vůlí všech. Hegel však upozorňuje, že konkrétní obecnost v duchovní oblasti došla „svého plného uznání“ právě v křest’anství, nebot' lidství je v něm chápáno jako neodlučitelný moment božství samého. Např. Řekové podle něj znali jen zvláštní bohy - „obecný bůh, bůh národů, byl pro Athéňany ještě skrytým bohem“. G. W. F. Hegel, Malá logika, § 163, 1. dodatek. 
Hegel připomíná, že představa božího vtělení, kdy božství na sebe přechodně či trvale bere lidskou podobu, je představou, na niž lze narazit v různých světových náboženstvích. Antropomorfismus těchto náboženství sice nepovažuje za příznak úpadkové, nýbrž spíše pokrokové tendence $\mathrm{v}$ dějinném vývoji náboženského vědomí směřujícího $\mathrm{k}$ adekvátnějšímu uchopení božské ideje. Nicméně se domnívá, že pouze křest'anství v porovnání s ostatními náboženstvími dovedlo antropomorfismus až do krajnosti. Je tedy výjimečné potud, že striktně odmítlo myšlenku vícečetných - simultánních i sukcesivních - inkarnací. Křest’anství se poprvé v dějinách náboženství snažilo uchopit vtělení a tělesnou stránku (včetně všeho, co s tělesností souvisí) jako něco, co není božské přirozenosti cizí - ba naopak, jako něco, co k ní bytostně patří. Tato snaha přichází ke slovu právě v představě jednoty božské a lidské přirozenosti. Ústřední rozdíl mezi křest’anstvím a ostatními světovými náboženstvími, ve kterých má představa vtělení jistě své místo, proto spočívá hlavně v tom, že ostatní náboženské systémy nepovažují událost božího vtělení za rozhodující krok směřující k překonání duality mezi Bohem/bohy a člověkem, duchem a matérií, oním a tímto světem apod. Implicitní dualismus, který je jim vlastní, je nakonec přivádí $\mathrm{k}$ tomu, že bohům či Bohu připisují existenci zcela nezávislou na člověku, matérii a vezdejším světě. To má za následek, že boží vtělení se považuje za přechodnou nebo nahodilou událost, jež pro božství není nikterak podstatná. Bůh se totiž mohl vtělit, ale také nemusel. I bez vtělení by zůstal tím, čím již beztak je. A pokud se přece jen vtělí a stane se např. člověkem, nezmění to nic na jeho povaze. Kvưli tomu Hegel akcentuje, že lidství je v nich ,pouhou maskou“ božství.

Křest’anské náboženství překonává zmiňované dualismy. Božská idea se totiž může plně uskutečnit pouze v matérii a v oblasti př́rody. Událost božího vtělení je tak krajností či „vyhrocením“ ducha, které je ovšem nutné, aby se Bůh mohl plně uskutečnit jakožto duch. To znamená: nejedná se o nahodilou událost. Zároveň v křest’anství není lidství považováno za pouhou „masku“, již na sebe božství přechodně bere, aby ji zas odložilo. Myšlenka jedinečnosti božího vtělení má svůj původ právě v uvedené představě, že lidství je nutný moment božství a že božská idea se stává matérii a vezdejšímu světu vskutku imanentní právě v podobě jedné jediné lidské bytosti. Jen tak lze dostát konkrétní obecnosti božství. ${ }^{34}$

34 V pozdních přednáškách Hegel podává ještě toto zpřesnění: „A zatímco v pantheismu dochází k nespočetným inkarnacím, nebot' subjektivita je v něm pou- 
Proti tomuto závěru lze ovšem namítnout, že konkrétní obecnost nelze sloučit s partikulárností. Zdá se, že universalistický nárok spojený s událostí božího vtělení je v př́krém rozporu s jedinečností této události. Jestliže pouze $\mathrm{v}$ jednom individuu mohou být zahrnuta všechna lidská individua - jak ř́ká Hegel: „,v jednom jsou všechna“-, vnucuje se otázka, jak tento inkluzivní vztah skloubit s partikulárností. Vždyt’ každá zvláštní osoba, která se k sobě vztahuje pomocí indexu ,jáa“, ze sebe všechny ostatní osoby vylučuje. A Ježíš byl také touto určitou osobou „zde“ a „nyní“.

Tento problém se v současných theologických diskusích nazývá „skandálem partikularity“. ${ }^{35}$ Má neblahé epistemologické a především soteriologické důsledky. Z epistemologického hlediska bychom museli konstatovat, že božská idea je epistemicky přístupná jen pro ty, kteří přišli do přímého kontaktu s Ježíšem Nazaretským. Ze soteriologického hlediska bychom museli tvrdit, že spasení je takto omezeno jen na nepatrný počet lidí. Jak se zdá, jedinečnost božího vtělení vlastně znemožňuje dosažení vědění o božské ideji pro každého člověka, resp. znemožňuje spasení každé lidské bytosti.

Hegel si byl dobře vědom argumentačního manévru kladoucího proti sobě universálnost a partikulárnost, resp. „skandálu partikularity“. Podle něj je nahodilou skutečností, že zrovna Ježíš Nazaretský exemplifikoval božskou ideu. Je tudíž myslitelné, že by ji mohl exemplifikovat někdo jiný. I tak pro něj zůstává logicky nutné, že se idea musela manifestovat $\mathrm{v}$ jednom jediném exempláři. Universalistický nárok události božího vtělení totiž může být naplněn jen tehdy, uznáme-li její jedinečnost. Je ovšem třeba správně vyložit jak tuto jedinečnost, tak universalistický nárok spojený s vtělením. Nelze mu např. rozumět tak, že by se božská idea musela bezprostředně zjevit ve smyslové podobě každému člověku, kdykoli a kdekoli. Je třeba jej chápat spíše tak, že idea se musela stát jednou provždy zjevnou člověku jako takovému. Ostatně toto chápání je vysloveno v jiném Hegelově tvrzení, že ,jednou znamená vždy“, resp. že na jednom místě znamená všude a že pro některé znamená pro všechny. ${ }^{36}$

ze akcidentální, Bůh se může jevit jako duch jen jednou jedinkrát, protože jedinečnost je vlastním momentem ducha." VPR III/1831, str. 169-172.

35 Srv. M. M. Adams, Chalcedonian Christology: A Christian Solution to the Problem of Evil, in: S. T. Davis (vyd.), Philosophy and Theological Discourse, London 1997, str. $186 \mathrm{n}$.

36 G. W. F. Hegel, VPR III/1821, str. 46/317-318. 


\section{Inkarnace a dějiny}

Hegelova filosofie náboženství a zejména jeho interpretace křest'anství se po filosofově smrti stala předmětem sporů nejen mezi jeho žáky, ale i mezi jeho odpůrci. Jedna z rozepř́i se přímo dotýkala ,skandálu partikularity“. Rozhodujícím způsobem ji podnítil Hegelův žák a posluchač jeho berlínských přednášek o filosofii náboženství theolog David F. Strauss. ${ }^{37}$ Ve svém raném spise Život Ježišư z roku 1835 přišel s provokativní interpretací starozákonních a novozákonních příběhů, když je označil za „filosofické mýty“, jež podávají myšlenkové obsahy, vyprodukované archaickým náboženským vědomím, ve figurativní formě. ${ }^{38}$ Strauss představil projekt demytologizace novozákonních příběhů o Ježíšově životě, působení a smrti a pokusil se očistit je od figurativní formy. ${ }^{39}$ V závěru spisu Život Ježí̌̌̌iov nakonec podrobil kritice christologii a samu ortodoxní nauku o božím vtělení. Straussova kritika spočívá, stručně řečeno, v tvrzení, že tato doktrína je bud'to nekoherentní, anebo je sama jen „filosofickým mýtem“. Jestliže s jejími výpověd’mi spojíme pravdivostní nárok, je nekoherentní naukou. A pokud s nimi žádný pravdivostní nárok

37 Spory okolo Hegelovy filosofie náboženství způsobily rozštěpení hegelovské školy na levé a pravé křídlo. Dnes již klasickou prací pojednávající (nejen) o těchto sporech a následném rozdělení stoupenců Hegela je K. Löwith, Von Hegel zu Nietzsche. Der revolutionäre Bruch im Denken des neunzehnten Jahrhunderts, Stuttgart $1964^{5}$, str. 350-415. Jak u nás v návaznosti na Löwitha upozornil Milan Sobotka, „[j]ádrem sporu byl rozpor o theistický či atheistický výklad Hegelovy filosofie náboženství, především teze, že absolutno-bůh má v lidském poznání své sebevědomi“. M. Sobotka, Člověk a práce v německé klasické filosofii, Praha 1964, str. 133.

38 Straussův interpretační přístup rozvířil polemiku a vzbudil ve své době odmítavé reakce. Erik Linstrum však poukazuje na to, že mnozí theologové již koncem 18. století zastávali podobné stanovisko, např. F. D. Schleiermacher dávno před Straussem dokonce tvrdil, že novozákonní příběhy o Ježíšově narození a dětství jsou pouhou fikcí. Srv. E. Linstrum, Strauss's ,Life of Jesus “: Publication and the Politics of the German Public Sphere, in: Journal of the History of Ideas, 4, 2010, str. 593.

39 Theolog Ingolf Dalferth proto tvrdí, že Straussův projekt je předchůdcem pozdějšího programu demytologizace, iniciovaného Rudolfem Bultmannem. I. Dalferth, Jenseits von Mythos und Logos. Die christologische Transformation der Theologie, Freiburg i. Br. 1993, str. 115-156. Rozsáhlou analýzu způsobu, jakým svůj demytologizační projekt Strauss uskutečnil, předkládá F. W. Graf, Kritik und Pseudo-Spekulation. David Friedrich Strauss als Dogmatiker im Kontext der positionellen Theologie seiner Zeit, München 1982. Stručné shrnutí Straussovy pozice lze nalézt in: H. Frei, David Friedrich Strauss, in: N. Smart - J. Clayton - S. Katz (vyd.), The Nineteenth Century Religious Thought in the West, I, Cambridge 1985, str. 215-260. 
nespojujeme, lze na ni pohlížet jako na „filosofický mýtus“. Je-li ovšem inkarnační doktrína „filosofickým mýtem“, znamená to, že theologické výpovědi - vědomky či nevědomky - se tímto snižují naroveň předmětu, o němž theologie chtěla vypovídat diskursivně a ne figurativně. Závěrečné partie Straussova díla lze proto číst jako pokus obnovit rozdíl mezi theologií a jejím předmětem, resp. jako snahu spojit s theologickými výpověd'mi pravdivostní nárok a zbavit inkarnační doktrínu inkoherence. Jedním slovem: Je to pokus demytologizovat samu theologii.

Strauss přitom sleduje dva cíle: jeden negativní, druhý pozitivní. ${ }^{40}$ Jednak výslovně polemizuje s Hegelem a s jeho tezí jedinečnosti božího vtělení, jednak nastiňuje vlastní spekulativní christologii, vycházející z přesvědčení, že událost božího vtělení může mít universální význam jen tehdy, odehrává-li se universálně. Strauss je totiž přesvědčen, že Ježíš Kristus nebyl paradigmatickým exemplářem jednoty božské a lidské přirozenosti, přestože za něj byl - a dosud je - pokládán společenstvím věřících. Ačkoli Strauss připouští, že tato víra byla svého času oprávněná, v našich podmínkách již ztratila opodstatnění, jelikož v našich podmínkách víra reaguje na odlišné potřeby; proto je víra, že Ježíš byl vpravdě Bohem a vpravdě člověkem, božím Synem a synem člověka, anachronismem.

Ještě než přikročím k analýze Straussovy teze o obecnosti božího vtělení, nastíním stručně, jak Strauss rekonstruuje (a kritizuje) Hegelovu pozici. Pro naše účely postačí, zhustíme-li tuto rekonstrukci do tř́i tvrzení, akcentujících popořadě: nutnost, dějinnost a jedinečnost božího vtělení. ${ }^{41}$ Podle prvního tvrzení se božská idea musí realizovat, a uskutečnit tak svůj pojem. Jinak by napořád zůstávala jen tím, co má být, aniž by měla realitu. Podle druhého tvrzení se božská idea může plně realizovat

40 Středem Straussovy pozornosti jsou především dvě otázky: Je nutné, aby se plné uskutečnění božské ideje vázalo na jednu dějinnou osobu Ježíše? Byl Ježíš skutečně bohočlověk? - Hodgson tvrdí, že právě tyto dvě provokativní otázky rozdmýchaly diskuse o rozporech přítomných v Hegelově interpretaci křestanství, a vlastně i poprvé nastolily otázku, do jaké míry lze posmrtnou edici Přednášek o filosofii náboženství z roku 1832, jež se opírala zčásti o Hegelovy vlastní rukopisné poznámky a z větší části pak o rozličné zápisy z přednášek pořízené jeho posluchači, považovat za opravdu spolehlivý zdroj poznatků o Hegelových vlastních názorech. Srv. P. C. Hodgson, Hegel's Christology: Shifting Nuances in the Berlin Lectures, in: Journal of the American Academy of Religion, 1, 1985, str. 23 n. Straussově interpretaci Hegela se věnuje třetí, obsáhlá poznámka Hodgsonova článku.

41 Podrobnější výklad lze nalézt in: D. F. Strauss, Život Ježišiov. Výběr ze svazku I a II, in: J. Pešek (vyd.), Výbor z filozofických spisů mladohegelovcü, I, přel. N. Pelcová - J. Pešek, Praha 1989, str. 43-93, str. 84 n. 
jen v dějinném jsoucnu. A ve třetím tvrzení se nakonec říká, že božská idea se plně realizuje pouze $\mathrm{v}$ jednom jediném individuu, a to $\mathrm{v}$ osobě Ježíše Krista, který je potud výlučným dějinným jsoucnem božské ideje. Strauss sice bez výhrad přitakává prvnímu a druhému tvrzení, nicméně zavrhuje tvrzení třetí. Soudí, že první a druhé tvrzení neospravedlňují přechod k třetímu tvrzení. Není podle něj nezbytné, abychom z nutnosti a dějinnosti božího vtělení činili krok k jeho jedinečnosti. Můžeme proto akceptovat první dvě tvrzení, aniž bychom přijali třetí, což také Strauss dělá, když v rámci své alternativní pozice podržuje nutnost a dějinnost božího vtělení a když dále prohlašuje, že dějinným jsoucnem božské ideje je obecná idea lidství neboli totalita lidského rodu.

Jak Strauss podkopává Hegelovu tezi jedinečnosti? ${ }^{42}$ Strauss v prvé řadě namítá, že tato teze, spojíme-li s ní pravdivostní nárok, činí christologii nekoherentní. Jedním z jejích přímých důsledků je okolnost, že jedné a téže osobě, o níž se tvrdí, že je vpravdě Bohem a vpravdě člověkem, se připisují neslučitelné vlastnosti. ${ }^{43} \mathrm{Je}$ sice představitelné, že božská idea se nutně realizuje v dějinném jsoucnu. Je rovněž myslitelné, že lidé si mohou uvědomit, co tvoří jejich vlastní bytostnost, jen prostřednictvím tohoto dějinného jsoucna a ne sami ze sebe. Přesto si lze podle Strausse jen stěží představit, ,jak božská a lidská přirozenost mohou být různými, a přece spojenými součástmi jedné dějinné osoby“، ${ }^{44}$ Jestliže přijímáme za pravdivou tezi jedinečnosti, bude christologie zatížena rozporem: bude ji tvořit soubor protikladných výpovědí. A to nás podle Strausse opravňuje k tomu, abychom zavrhli tezi jedinečnosti.

Hegel by však na přednesenou kritiku mohl reagovat slovy, že pokud zavrhneme tezi jedinečnosti, zpochybníme tím také nutnost a dějinnost realizace božské ideje. Není-li totiž idea plně realizována v jednom výlučném dějinném jsoucnu, je namístě pochybnost, zdali tato idea má vůbec nějakou realitu, protože jen v jedné jediné osobě může dojít $\mathrm{k}$ její plné realizaci. A není-li plně realizována $\mathrm{v}$ jedné osobě, zůstává

42 Jedinou mně známou důkladnější studií koncentrovaně pojednávající o polemice mezi Hegelem a Straussem ve světle otázky týkající se jedinečnosti, resp. obecnosti božího vtělení je pronikavá práce Daniela P. Jamrose, S. J. Srv. D. P. Jamros, Hegel on the Incarnation: Unique or Universal?, in: Theological Studies, 56, 1995, str. 276-300. Jamros analyzuje Hegelovy dvojznačné interpretace ve Fenomenologii ducha a v Přednáškách o filosofii náboženství, a přitom dává za pravdu Straussovi, který se domníval, že jeho rekonstrukce christologie fakticky rozvíjí implikace, přítomné v Hegelově stanovisku v otázce božího vtělení.

43 D. F. Strauss, Život Ježišuiov, str. 85.

44 Tamt. 
nadále - alespoň zčásti - něčím neuskutečněným, a tedy pouze možným. Jestliže idea není plně uskutečněna, lze říci, že postrádá dějinné jsoucno. Tím se však bortí celá christologická konstrukce, poněvadž ztrácí svůj substanciální základ. Hegel by tedy mohl Straussovi jednoduše odpovědět, že jeho demytologizační úsilí, postihující nejenom novozákonní př́běhy, ale i křest'anskou theologii, de facto vyprazdňuje christologii, čímž přispívá k jejímu zhroucení. Není bez zajímavosti, že Strauss si tohoto důsledku byl vědom, jelikož v samém závěru své knihy poznamenává: „Tak na konci kritiky životopisu Ježíšova vyplývá úkol to, co bylo zničeno, dogmaticky obnovit.“45 Strauss se tedy snaží „dogmaticky obnovit“" christologii a přijít se svojí alternativou, která by odhalila spekulativní jádro Ježíšova života, učení a smrti. Krok od destrukce k rekonstrukci odhaluje ambivalenci Straussova vlastního demytologizačního projektu. ${ }^{46}$

Strauss se s Hegelovou pomyslnou reakcí vypořádává poměrně snadno. Předně podtrhuje, že odmítnutí jedinečné reality božské ideje nezahrnuje negaci teze, že ideji obecně vzato náleží realita a dějinné jsoucno. Jeho protitah se tedy zakládá na striktním odlišení jedinečné a obecné reality, resp. dvou druhů dějinného jsoucna ideje: jednak jsoucna jednoho člověka, jednak jsoucna lidského rodu.

Naráz se tak ocitáme u Straussovy teze obecnosti božího vtělení. Tato teze říká, že božská idea má své dějinné jsoucno v obecné ideji lidství neboli v totalitě lidského rodu. $V$ ústřední pasáži je tato teze představena následovně: ,To přece není vůbec způsob, jak se realizuje idea, vydat celou svou plnost na jeden exempláŕ a vůči všem ostatním skrblit. ... Nebude naopak idea jednoty božské a lidské přrirozenosti reálná v nekonečně vyšším smyslu, pochopím-li jako její uskutečnění celé lidstvo, než když jako toto uskutečnění vyčlením jednotlivého člověka? Není stávání se Boha člověkem od věčnosti pravdivější než stávání se jím

45 Tamt., str. 48.

46 Warren Breckman v této souvislosti poznamenává: „Když dnes čteme Strausse, nelze si nevzpomenout na poznámku Heinricha Heineho. Heine říká, že Kantova kritická obhajoba víry v Boha mu připomíná jednoho jeho starého přítele ze studentských let, který navečer rozbil všechny pouliční lampy ve městě, aby mohl druhý den kázat o tom, jak potřebné je pouliční osvětlení.“ Strauss podobně provede destrukci christologie, aby mohl v závěru svých úvah „kázat“ o potřebnosti christologie. Srv. W. Breckman, The Symbolic Dimension and the Politics of Left-Hegelianism, in: D. Moggach (vyd.), The New Hegelians. Politics and Philosophy in the Hegelian School, Cambridge 2006, str. 77. Dotyčné místo se nachází in: H. Heine, $K$ dějinám náboženství a filosofie v Německu, in: týž, O Německu, přel. K. Jiroudková - A. Siebenscheinová, Praha 1951, str. 132. 


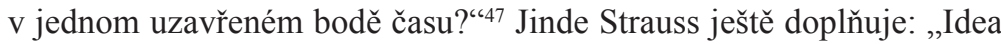
ráda širrí své bohatství v mnohotvárnosti exemplářù, které se navzájem doplňují, ve stř́iání individuí, jež se kladou a opět ruší."“8 Obě ocitované pasáže obsahují mj. odpověd’ na otázku, jak přesně Strauss rozumí nutnosti a dějinnosti realizace božské ideje. Domnívá se, že idea se realizuje v pluralitě individuí, a dokonce $\mathrm{v}$ jejich totalitě. Je tomu tak $\mathrm{z}$ toho důvodu, že ideji, která se realizuje hned v několika nebo eventuálně ve všech individuích, náleží více reality nežli ideji, jež se realizuje pouze v jednom individuu. To, že se individua v průběhu dějin doplňují, stř́dají, vznikají a zanikají, je v naznačeném pojetí teleologickým procesem, v jehož průběhu se Bůh od věčnosti stává lidstvem. Teze obecnosti božího vtělení tímto imunizuje christologii vůči hrozbě inkonsistence, jelikož problém připisování nekompatibilních vlastností jedné dějinné osobě odpadá. Subjektem christologických predikátů se nyní stává lidský rod či přesněji: obecná idea lidství realizující se v dějinách. ${ }^{49}$

Jestliže nelze Ježíše Krista považovat za paradigmatický exemplář jednoty božské a lidské přirozenosti, za něhož je považován společenstvím věřících, vyvstává otázka, jakou úlohu mu vlastně máme připisovat. Straussova odpověd' vyznívá v tom smyslu, že Ježíš pro člověka zůstává důležitým vnějším popudem, který jej přivádí $\mathrm{k}$ tomu, aby se odpoutal od smyslového ,zde“ a „nyní“, tj. od empirické bezprostřednosti a své konečné existence, a učinil krok směrem $\mathrm{k}$ duchovní sféře, $\mathrm{v}$ níž může diskursivně uchopit, a tedy i myslet božskou ideu, resp. obecnou ideu lidství. Právě tato odpověd' Straussovi vysloužila nálepku ebionity, který údajně zamýšlí snížit Spasitele na úroveň obyčejného člověka-učitele. Strauss nicméně uvedené nařčení odmítá, když ve zjevné narážce na Hegela tvrdí: „Smyslové dějiny individua... jsou jen východiskem

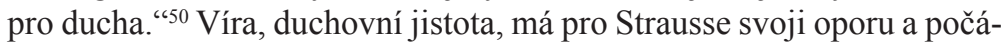
tek ve smyslové jistotě či přesněji: $v$ jejím obsahu, v něčem, co je nám bezprostředně dáno. Od danosti a názoru výjimečného člověka je ovšem třeba postoupit k pojmovému zprostředkování a k myšlení obecné ideje lidství, jež Straussovi spadá vjedno s ideou božství. Přerod smyslové

47 D. F. Strauss, Život Ježiššio, str. 85.

48 Tamt.

49 Tamt., str. 86. Srv. též: „Lidstvo je sjednocením obou přirozeností, je Bohem, jenž se stal člověkem, je do konečnosti odcizeným nekonečným a na svou nekonečnost si vzpomínajícím duchem... Lidstvo je umírající, vstávající z mrtvých a vstupující na nebesa." Tamt.

50 Tamt., str. 87. 
jistoty v jistotu duchovní a postup od jednotlivého k obecnému vrcholí, podobně jako u Hegela, ve filosofii, v níž se uchopuje náboženský obsah diskursivně.

\section{Hegel versus Strauss}

Nezodpovězena zatím zůstává otázka, je-li Straussova christologická konstrukce pouhým rozvinutím implikací Hegelovy metafyziky božího vtělení, anebo jejím naprostým přetvořením. Je třeba hned zkraje poznamenat, že Strauss postřehl napětí přítomné v Hegelově inkarnační a dějinné koncepci a pokusil se je oslabit zavedením teze obecnosti božího vtělení. Hlavním zdrojem napětí je podle něj střet teze jedinečnosti s představou, že každý člověk je „o sobě“ instancí jednoty božské a lidské prrirozenosti.

Hegel, jak známo, chápe dějiny jako teleologicky strukturovaný proces, během něhož se postupně realizuje pojem ducha. Tento proces se završí v momentě, kdy duch dospívá k sebeuvědomění skrze jiného ducha, díky čemuž mu připadne určení svobody, jež tkví v tom, že duch je v jiném u sebe sama. Je-li však duch pojmem či substancí každého jednotlivého člověka a člověka jako takového, je realizace vnitřního pojmu ducha současně procesem, v němž také dochází k realizaci vnitřního pojmu člověka (a totéž platí i opačně). Viděno z tohoto úhlu jsou dějiny jednak postupnou universalizací vědomí svobody, jednak propůjčováním dějinného jsoucna tomuto vědomí, a to ve společenských institucích, v systému společenských norem a pravidel apod. Oba souběžné procesy pro Hegela tvoří nejvlastnější látku dějin. ${ }^{51}$

Inkarnační koncepce má u Hegela podobné východisko jako dějinná koncepce. Je jím představa, podle které každý člověk je „o sobě“ instancí božské ideje, chápané jako původní vědění o sobě samém. To, co utváŕí pojem člověka, v něm však není plně rozvinuto, a proto lidské bytosti nejsou ve své bezprostřední existenci v souladu se svým pojmem. To je úděl, nad nímž se Hegel pozastavuje již v raných textech z jenského období, když hovoří o rozdvojení, které nemá jen metafyzickou nebo epistemologickou dimenzi, nýbrž především existenciální rozměr. Formuje totiž přístup člověka ke světu, k Bohu i k sobě samému. Rozdvojení je v Hegelově metafyzice božího vtělení reinterpretováno jako rozdíl mezi božskou a lidskou přirozeností, jako odloučenost Boha od člověka, přičemž není v lidských silách ji překonat a dosáhnout

51 G. W. F. Hegel, Filosofie dějin, přel. M. Váňa, Pelhřimov 2004, str. 19. 
smíření protikladných stránek a v důsledku toho i spasení. K překonání rozdvojení a ke smíření Boha a člověka je zapotřebí prostředníka, který v předmětné podobě zjeví, že božská a lidská přirozenost jsou původně sjednocené. Toto přesvědčení je neuralgickým bodem Hegelových úvah o božím vtělení. Z hlediska dějinné koncepce se však tento bod může jevit jako nadbytečný. Jsou-li totiž dějiny realizací pojmu božské ideje, „o sobě“ přítomné v člověku, jsou zároveň postupným překonáváním rozdvojení, a tedy i dosahováním smíření a potažmo spasení. - Právě na tuto okolnost poukazuje v Životě Ježišsově Strauss, když konstatuje, že dějiny jsou polem, na němž se realizuje božská idea, kterou klade naroveň obecné ideji lidství. ${ }^{52}$ Odmítnutím teze jedinečnosti jako nadbytečného christologického dodatku zneutralizoval napětí mezi Hegelovou inkarnační a dějinnou koncepcí. Zdá se tedy, že Strauss pouze rozvinul implikace př́tomné v Hegelově metafyzice božího vtělení.

Proti tomu je možno namítnout, že napětí mezi inkarnační a dějinnou koncepcí je spíše domnělé a že jeho zneutralizování při uchování Hegelovy intence je ve skutečnosti zásadním přetvořením jeho metafyziky božího vtělení. Strauss totiž přehlédl jednu podstatnou věc. Pokrok v sebeuvědomování a s ním související universalizace vědomí svobody je u Hegela spojován s klíčovým dějinným okamžikem, jímž je vznik křest'anství. Hegel říká: „To, že si lidstvo uvědomuje konkrétno takto v jeho završení jako Boha, to způsobuje naprostý obrat ve světových dějinách. "53 Vznik křest'anství představoval dějinný zvrat. Křest'anská zvěst totiž učinila prvně v dějinách explicitním obsah, že božská a lidská přirozenost tvoří jednotu. A tento obsah učinila zjevným právě na životě, učení a útrpné smrti Ježíše Krista. Řečené je významnou indicií, že dějinná a inkarnační koncepce se u Hegela doplňují. Nebot' jedinečnost události božího vtělení je nutnou podmínkou universalizace vědomí svobody tvořící substanciální základ moderních institucí a státu. V inkarnační koncepci Hegel snáší ve prospěch tohoto tvrzení epistemologické a metafyzické, nikoli empirické a historické důvody.

To, že Straussova interpretace je přetvořením a ne rozvinutím Hegelovy metafyziky božího vtělení, se stává zřejmějším při pohledu na jeho christologickou konstrukci a zejména na ohlas, který zaznamenala. Představovala totiž rozhodující krok ke kritice náboženství, jak ji vzápětí

52 Jak trefně uvádí Ladislav Major, Strauss rozšířil ,,akt božího zjevení na celý historický vývoj lidstva“ a ztotožnil „Boha a boží zjevení s vývojovým pohybem lidstva“. L. Major, Od úpadku hegelovství k novohegelovství, Praha 1986, str. 18.

53 G. W. F. Hegel, Dějiny filosofie, III, přel. J. Bednář - J. Husák, Praha 1974, str. 71 . 
rozvinul Ludwig Feuerbach. Ten se v př́mé návaznosti na Strausse snažil zredukovat „,mimosvětskou, nadpřirozenou a nadlidskou bytost boží na součásti lidské bytosti jako na její součásti základní“, a tím dovršit obrat od theologie $\mathrm{k}$ antropologii. Není výmluvnějš́ího svědectví o tomto obratu nežli věta vyslovená ve zjevné narážce na Hegelovu interpretaci náboženství: „Člověk je počátek náboženství, člověk je ústřední bod náboženství, člověk je konec náboženství. " ${ }^{54}$

\section{ZUSAMMENFASSUNG}

Der Beitrag befasst sich mit Hegels Metaphysik der Menschwerdung Gottes. Sie ist ganz klar soteriologisch ausgerichtet, denn der Zweck der Menschwerdung Gottes wird in der Erlösung gefunden. Jedoch stellt man fest, dass Hegel diesen Rahmen auch zum Teil modifiziert. Er hebt deutlich hervor, dass es keine Erlösung ohne Menschwerdung gibt. Gleichzeitig betrachtet er das Wissen als das wichtige Element, das zwischen der Inkarnation und der Erlösung vermittelt. Hegel konzentriert sich deswegen zuerst auf die Entdeckung der epistemischen Bedingungen - sowohl der notwendigen, als auch der ausreichenden -, die die gottmenschliche Einheit für den Menschen epistemisch zugänglich machen sollen. Dann zieht er daraus gewisse metaphysische Folgerungen bezüglich der Inkarnation, die näher analysiert und diskutiert werden (vor allem die Einzigartigkeit der Menschwerdung Gottes). Weiter werden die Einwände rekonstruiert, die David F. Strauss in seinem Das Leben Jesu gegen Hegel und die Einzigartigkeit der Menschwerdung Gottes erhoben hat. Zum Schluss werden diese Einwände im Kontext von Hegels Inkarnationskonzeption und seiner Geschichtsphilosophie erwogen.

SUMMARY

The paper deals with Hegel's metaphysics of God incarnate. Although it has a firm soteriological grounding, as the aim of incarnation is believed

54 L. Feuerbach, Podstata křestanství, přel. Z. Sekal, Praha 1954, str. 238. Hegel v rukopise Přednášek o filosofii náboženství oproti tomu říká: „Bůh je východisko všeho a konec všeho; z něj všechno pochází a do něj se všechno navrací.“ G. W. F. Hegel, Vorlesungen über die Philosophie der Religion. Einleitung. Der Begriff der Religion, Hamburg 1993, str. 3. 
to be salvation, Hegel also slightly modifies this framework, assuming more strictly that there is no salvation without incarnation. At the same time he considers knowledge to be a key element which mediates between incarnation and salvation. Accordingly, Hegel's main interest lies in detecting epistemic conditions - both necessary and sufficient - that make the unity of God and human epistemically accessible for us, and follows up with some metaphysical conclusions concerning the nature of incarnation itself. The paper analyses and discusses these conclusions, especially focusing on unique character of incarnation. The attention is further paid to objections raised by David F. Strauss's Das Leben Jesu, arguing against uniqueness of God incarnate. Finally, these objections are re-examined within a context of both Hegel's incarnational metaphysics and his philosophy of history. 